ISSN 0103-5150

Fisioter. Mov., Curitiba, v. 29, n. 1, p. 121-30, Jan./Mar. 2016

Licenciado sob uma Licença Creative Commons

DOI: http://dx.doi.org.10.1590/0103-5150.029.001.A013

(c) (i)

\title{
Influence of side-shift therapy associated or not with a shoe lift on idiopathic scoliosis
}

\author{
Influência da inclinação lateral associado ou \\ não ao calço na escoliose idiopática
}

\begin{abstract}
Crystian Bitencourt Oliveira, Cristina Elena Prado Teles Fregonesi, Célia Aparecida Stellutti Pachioni, Maria Rita Masselli, Dalva Minonroze Albuquerque Ferreira*
\end{abstract}

Universidade do Estado de São Paulo, (UNESP), Presidente Prudente, SP, Brazil

\begin{abstract}
Introduction: The benefits of side-shift therapy associated with a shoe lift in scoliosis can act by reorganizing the asymmetries found in these individuals. The aim of this study was to analyze the influence of sideshift therapy with or without a high or low shoe lift in patients with idiopathic scoliosis. Materials and Methods: 10 individuals of both genders, aged 13-24 years, were selected, with scoliosis "S" and right thoracic and left lumbar greater than $10 \%$. Initially the order of the task was static and then dynamic, after which there was a draw for the conditions with the shoe lift. The values of postural angles during the five lateral tilt movements were obtained and also the minimum and maximum values of each movement. The average value of postural angle in the static position, without a shoe lift, was used as a reference. Results: The movement associated with the shoe lift demonstrated less significant results compared with the effect of the
\end{abstract}

* CBO: grad, e-mail: crystianbso@hotmail.com CEPTF: PhD, e-mail: cristina@fct.unesp.br CASP: PhD, e-mail: pachioni@fct.unesp.br MRM: PhD, e-mail: mrm@fct.unesp.br DMAF: PhD, e-mail: dalva@fct.unesp.br 
static shoe lift and the side-shift movements performed in isolation, no significant results in any angle were found. Discussion: Both movements, to the side of the convexity or to the opposite side, seemed to decrease the effect of the shoe lift. The side-shift movement performed in isolation failed to influence the postural angles in general, demonstrating that acute intervention may not be efficient. Conclusion: The influence of side-shift therapy associated with a high or low shoe lift on both sides was effective, but the shoe lift in the static position produced the most significant changes and therefore is considered a better intervention in order to prevent the progression of double curve in patients with idiopathic scoliosis.

Keywords: Scoliosis. Posture. Cinematic. Pinal curvatures.

\section{Resumo}

Introdução: Os benefícios dos exercícios de inclinação lateral associado ao calço na escoliose pode atuar reorganizando as assimetrias encontradas nestes indivíduos. O objetivo do estudo foi analisar a influência do movimento de inclinação lateral associado ou não ao calço em indivíduos com escoliose idiopática. Materiais e Métodos: Foram selecionados 10 indivíduos de ambos os gêneros na faixa etária de 13 a 24 anos com escoliose em "S", torácica direita e lombar esquerda maiores que $10^{\circ}$. Inicialmente a ordem da tarefa foi estática e posteriormente dinâmica, após isso houve o sorteio das condições com o calço. Os valores dos ângulos posturais durante os cinco movimentos de inclinação lateral foram obtidos, assim como os valores mínimos e máximos para cada angulo. $O$ valor médio dos ângulos posturais na posição estática, sem calço, foi usado como referência. Resultados: o movimento associado ao calço obteve resultados menos significativos em comparação com o efeito do calço na posição estática e nos movimentos de inclinação lateral realizados isoladamente, não houve resultados significativos em nenhum ângulo. Discussão: o movimento, tanto para o lado da convexidade como para o lado oposto, parece influenciar de maneira a diminuir o efeito do calço isoladamente. $O$ movimento de inclinação lateral realizados isoladamente não conseguiram influenciar nos ângulos posturais de maneira geral, demonstrando que uma intervenção aguda apenas talvez não seja eficiente. Conclusão: A influência do movimento de inclinação lateral associado ao calço alto e baixo em ambos os lados se mostrou eficaz, contudo só o calço na posição estática produziu mudanças mais significativas e, portanto, sendo considerado uma melhor intervenção no sentido de evitar a progressão de curvas duplas em indivíduos com escoliose idiopática.

Palavras-chave: Escoliose. Postura. Cinemática. Curvaturas da coluna.

\section{Introduction}

Scoliosis is an abnormal spatial arrangement of individual body segments which the Central Nervous System (CNS) interprets as a defect and thus automatically launches compensatory mechanisms (1).The most common type of scoliosis is defined as idiopathic that has unknown pathogenesis, in other words, any disease, injury or mutation that entails a set of disabilities or deterioration of any component might result in the development of this kind of scoliosis.

The likelihood of progression is higher in girls and in children with a large curvature and remaining growth (6). To avoid the curvature progression of the scoliosis there are many conservative treatments, among which electrical stimulation, physical exercises, manipulation, insoles and braces can be mentioned (7). The main goals that the patients hope to achieve with these treatments are: stop the curvature progression at puberty, prevent the treatment of a respiratory dysfunction or a back pain syndrome and improve aesthetics through postural correction.

The deformity determines the treatment of the idiopathic scoliosis (8). Side-shift exercises are used as a conservative treatment for scoliosis, consisting of an auto correction of the spine curve through a lateral shift of the trunk to the concavity of the curve (7). Stehbens and Cooper (9) studied the effects of the side-shift exercise to the side of the scoliotic curve convexity in sitting, standing and supine positions to reduce the primary curve. The proposed exercise program restored the vertebrae and intervertebral discs to a more appropriate position with regression of the scoliotic curve. 
In addition, the early stages of functional scoliosis, associated with lower limb length discrepancy, can be corrected with the use of shoe lifts to reduce these postural asymmetry generators $(3,10)$. Thus, the primary goal of the shoe lift is to decrease the compensations that occur in idiopathic scoliosis due to information reorganization, to maintain the postural stability compensation brings, thereby aligning the feet, knees, pelvis, scapula and shoulders (11-14).

Therefore, due to the scarcity of research related to the effectiveness of conservative treatment in idiopathic scoliosis (15) the main goal of the present study was to assess the influence of the side-shift movement, associated or not with the use of high or low shoe lifts, in subjects with idiopathic scoliosis.

\section{Materials and methods}

Ten subjects of both genders, aged from 13 to 24 years, were selected. with "S" scoliosis and right thoracic and left lumbar greater than $10^{\circ}$, confirmed by Cobb angle measurements in a radiological examination, characterizing structural curves $(16,17)$.

The subjects, their parents or a legal representative signed an Informed Consent approved by the local Research Ethics Committee as an extension of the Project previously approved with the same methodology (CEP 124/2009). The exclusion criteria were: use of prosthesis and/or orthesis, surgery performed on the spine, pregnancy and scoliosis of non-idiopathic etiology (4).

Initially, personal information and anthropometric measurements, such as weight, height, BMI (Body Mass Index) and lower limb length were assessed. Next, the subjects attended the Laboratory of Physiotherapy Applied to Human Movement (Laboratório de Fisioterapia Aplicada ao Movimento Humano) of the Faculty of Science and Technology/ UNESP - Presidente Prudente Campus for realization of the experimental procedures. The subjects wore bathing suits for the placement of markers at specific anatomic points. These points were defined based on previous studies (18-20), with 10 reflective markers, $13 \mathrm{~mm}$ in diameter, being placed on the spine of each subject at the following anatomic points: spinous process of the seventh cervical vertebra (C7); spinous process of the second (T2), fourth (T4), sixth (T6), eighth (T8), tenth (T10) and twelfth (T12) thoracic vertebrae; spinous process of the second (L2) and fourth (L4) lumbar vertebrae and at the medial sacral crest.

The subjects were filmed with three cameras (Panasonic, models PVGS180 and PVGS320), placed on wall brackets, arranged within the collection area and oriented following the calibration system of volume coordinates ( $\mathrm{x}, \mathrm{y}$ and $\mathrm{z}$ axis) to perform the calibration. The calibration was composed of a tridimensional reference system with 12 points of control and a volume of 1,07 x 1,66 x 1,23 m (length, height and depth, respectively).

Initially the task order was static, followed by dynamic (right side-shift movement or left side-shift movement); after which there was a draw to define the condition (low or high shoe lift, right or left foot), the order was recorded and the collection followed this order. In table 1 the order is merely explanatory: in the first trial the condition was without a shoe lift and a static filming of the subject in a "nominal position" was performed, with the marker already placed, for about 15 seconds.

Table 1 - Collection steps divided into trials, conditions and tasks performed by the control and experimental groups

\begin{tabular}{|c|c|c|}
\hline Trial & Condition & Task \\
\hline 1 & no shoe lift & Static \\
\hline 2 & no shoe lift & $\begin{array}{l}\text { shift side to the } \\
\text { right }\end{array}$ \\
\hline 3 & no shoe lift & side-shift to the left \\
\hline 4 & $\begin{array}{l}\text { right shoe lift } \\
\quad(1 \mathrm{~cm})\end{array}$ & $\begin{array}{l}\text { side-shift to the } \\
\text { right }\end{array}$ \\
\hline 5 & $\begin{array}{l}\text { right shoe lift } \\
\quad(1 \mathrm{~cm})\end{array}$ & side-shift to the left \\
\hline 6 & $\begin{array}{l}\text { left shoe lift } \\
\qquad(1 \mathrm{~cm})\end{array}$ & $\begin{array}{l}\text { side-shift to the } \\
\text { right }\end{array}$ \\
\hline 7 & $\begin{array}{l}\text { left shoe lift } \\
\qquad(1 \mathrm{~cm})\end{array}$ & side-shift to the left \\
\hline 8 & $\begin{array}{l}\text { right shoe lift } \\
\qquad(3 \mathrm{~cm})\end{array}$ & $\begin{array}{l}\text { side-shift to the } \\
\text { right }\end{array}$ \\
\hline 9 & $\begin{array}{l}\text { right shoe lift } \\
\qquad(3 \mathrm{~cm})\end{array}$ & side-shift to the left \\
\hline 10 & $\begin{array}{l}\text { left shoe lift } \\
\qquad(3 \mathrm{~cm})\end{array}$ & $\begin{array}{l}\text { side-shift to the } \\
\text { right }\end{array}$ \\
\hline 11 & $\begin{array}{l}\text { left shoe lift } \\
\qquad(3 \mathrm{~cm})\end{array}$ & side-shift to the left \\
\hline
\end{tabular}


The trial was filmed and then recorded on MiniDV video tapes. Posteriorly, the images were captured using the CapDV mode in the software Ariel Performance Analysis System (APAS version 1.4), after which the images were treated using Trimer, Digitize, Transform Filter and Display.

Figure 1 features the convention used to calculate the angles based on the studies by Engsberg et al. (18) and Feipel et al. (19), adapted to measure postural angles in this study. Four spine postural angles were obtained in the frontal plane: two in the thoracic region; the first angle was in the high thoracic, denominated angle $\alpha 1$, formed by T2T4 -T4T6 markers and angle $\alpha 2$ in the middle thoracic, formed by T6T8b - T8T10 markers; one in the thoracolumbar region, denominated $\alpha 3$ and formed by T10T12 - T12L2 markers; and one in the lumbar region denominated $\alpha 4$ formed by L2L4 - L4S1 markers.

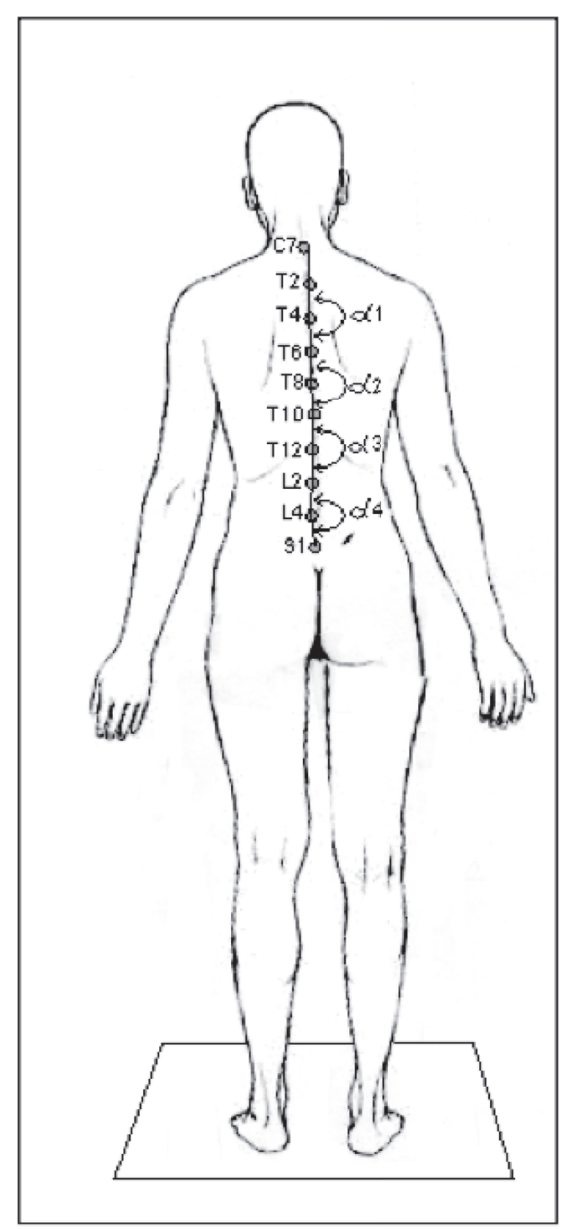

Figure 1 - Representation of the spine postural angles in the frontal plane, with the al angle in the thoracic region, a2 angle in the middle thoracic region, a3 angle in the thoracolumbar region and a4 angle in the lumbar region
The data obtained in the condition, maintenance of static posture without shoe lift, were used to identify the postural angle configuration in the orthostatic position and their absolute values were determined. The intermediary five seconds of the 15 seconds of footage collected were digitalized using APAS and the standard deviation and mean of these angles were also calculated. An average value of postural angles lower than $180^{\circ}$ represented a curvature to the left and an average value of postural angles greater than $180^{\circ}$ represented a curvature to the right.

Conditions with side-shift movement to the left or right were used to identify the behavior of the same angles in dynamic situations. Thus, five sideshift movements to the right and five side-shifts to the left were digitalized and analyzed.

Postural angle values and minimum and maximum values while executing the five side-shift movements were obtained for each movement. The average value of postural angles in the static position, without a shoe lift, was used as a reference to perform another subtraction related to the average value of the previously calculated maximum and minimum postural angles. From these data, the influence that the side-shift movement with or without a shoe lift (high or low) would produce as an immediate effect on the curves of the subject with idiopathic scoliosis, represented by the postural angles, was analyzed.

Minimum and maximum values were obtained from each angle and subtracted from the average value of the respective angle in the static position. Next, the average of these subtractions was calculated, for both values, for each angle of each situation, involving all subjects. From these data, how much each maximum and minimum average value influenced the postural angles, regarding the static position, was analyzed, in order to rectify them (angles near $180^{\circ}$ ).

Negative average values were analyzed as if they were positive. For example, in the case of a subject executing a task determined by the draw and having a minimum $\alpha 2$ angle of $183^{\circ}$, while in the static position the $\alpha 2$ angle was $185^{\circ}$, the subtraction between the condition and the static position would be -2 . Assuming this value repeats for all the subjects for the same condition the average value would be negative, however, even with negative values, a statistically significant difference was observed in order to rectify the curvature, approaching $180^{\circ}$. Therefore, there is no interference in the signal of the average values, but whether the difference was, or not, in order to rectify 
the spine curvature through the task the subject was asked to perform.

Data were analyzed using the statistical software SAS and the significance level was set at 0.05 . For the side-shift comparison, the Sign test was used; a non-parametric procedure for hypothesis testing using small samples, when there is no requirement for data normality and unknown population distribution.

\section{Results}

The 10 subjects (age $=20.0 \pm 2.87$ years; weight $=$ $55.65 \pm 9.48 \mathrm{~kg}$; height $=1.67 \pm 0.09 \mathrm{~m} ; \mathrm{BMI}=18.92$ $\pm \mathrm{Kg} / \mathrm{m} 2$ ) with "S" scoliosis, with right thoracic curve $\left(17^{\circ} \pm 8.8^{\circ}\right)$ and left lumbar curve $\left(15^{\circ} \pm 7.9^{\circ}\right)$, were analyzed during side-shift movements in isolation or associated with high or low shoe lifts and also in the static position with high or low shoe lifts.

Table 2 features the difference between means (maximum and minimum) of $\alpha 1, \alpha 2, \alpha 3$ and $\alpha 4$ in side-shift movements to the right with shoe lifts of $1 \mathrm{~cm}$ and $3 \mathrm{~cm}$ in relation to the static position and $\mathrm{p}$ value.

Table 3 features the difference between postural angle means in situations that involved side-shift movements to the left with shoe lifts on both sides.

Besides the dynamic situation, allied to the shoe lift, only the influence of high or low shoe lifts in the static position were analyzed, in relation to the minimum and maximum angles of each intervention (Table 4).

Table 2 - Difference between means (maximum and minimum) of $\alpha 1, \alpha 2, \alpha 3$ and $\alpha 4$ in side-shift movements to the right with shoe lifts of $1 \mathrm{~cm}$ and $3 \mathrm{~cm}$ in relation to the static position and $p$ value

\begin{tabular}{|c|c|c|c|c|c|c|c|c|}
\hline \multirow{2}{*}{$\begin{array}{l}\text { A } \\
\text { N } \\
\text { G } \\
\text { L } \\
\text { E } \\
\text { S }\end{array}$} & \multicolumn{2}{|c|}{$\begin{array}{l}\text { Right Side-shift } \\
1 \mathrm{~cm} \text { right shoe lift }\end{array}$} & \multicolumn{2}{|c|}{$\begin{array}{l}\text { Right Side-shift } \\
3 \mathrm{~cm} \text { right shoe lift }\end{array}$} & \multicolumn{2}{|c|}{$\begin{array}{l}\text { Right Side-shift } \\
1 \mathrm{~cm} \text { left shoe lift }\end{array}$} & \multicolumn{2}{|c|}{$\begin{array}{l}\text { Right Side-shift } \\
3 \mathrm{~cm} \text { left shoe lift }\end{array}$} \\
\hline & Mean (SD) & $\mathrm{P}$-value & Mean (SD) & $\mathrm{P}$-value & Mean (SD) & $\mathrm{P}$-value & $\begin{array}{l}\text { Mean } \\
(\mathrm{SD})\end{array}$ & $\mathrm{P}$-value \\
\hline$\alpha 1 \mathrm{Min}$ & $-5.6(11.5)$ & 0.37 & $-2.55(7.4)$ & 0.37 & $-2.2(5.8)$ & 0.19 & $-5.0(11.5)$ & $0.03^{*}$ \\
\hline$\alpha 1$ Max & $1.36(2.7)$ & 0.54 & $1.41(3.0)$ & 0.19 & $0.27(2.7)$ & 0.37 & $-1.37(2.9)$ & 0.16 \\
\hline$\alpha 2$ Min & $-2.49(6.4)$ & 0.49 & $-1.24(1.6)$ & $0.01^{*}$ & $-0.47(1.0)$ & 0.32 & $-2.19(6.3)$ & 0.49 \\
\hline$\alpha 2 \operatorname{Max}$ & 2.87 (5.2) & 0.13 & $1.51(5.8)$ & 0.23 & $1.01(5.2)$ & 0.69 & $-0.56(1.9)$ & 0.62 \\
\hline$\alpha 3 \mathrm{Min}$ & $-0.93(6.2)$ & 1.00 & $-1.95(4.9)$ & 0.23 & $-1.16(7.3)$ & 0.56 & $2.03(2.3)$ & 0.08 \\
\hline$\alpha 3 \operatorname{Max}$ & $-1.18(6.1)$ & 0.92 & $-1.87(4.6)$ & 0.16 & $-1.24(7.9)$ & 0.32 & $2.86(4.3)$ & $0.05^{\star *}$ \\
\hline$\alpha 4$ Min & $1.31(4.1)$ & 0.56 & $-0.1(6.5)$ & 0.32 & 1.99 (3.2) & 0.08 & $2.76(3.8)$ & 0.08 \\
\hline$\alpha 4 \operatorname{Max}$ & $0.21(2.8)$ & 0.92 & $-0.54(5.9)$ & 0.43 & $2.2(2.9)$ & $0.05^{\star *}$ & $3.74(5.0)$ & $0.05^{\star *}$ \\
\hline
\end{tabular}

Note: ${ }^{*} p<0.05$

** marginal difference

Table 3 - Difference between means (maximum and minimum) of $\alpha 1, \alpha 2, \alpha 3$ and $\alpha 4$ in side-shift movements to the left with shoe lifts of $1 \mathrm{~cm}$ and $3 \mathrm{~cm}$ in relation to the static position and $p$ value

(To be continued)

\begin{tabular}{|c|c|c|c|c|c|c|c|c|}
\hline \multirow{2}{*}{$\begin{array}{l}\text { A } \\
\text { N } \\
\mathbf{G} \\
\mathbf{L} \\
\mathbf{E}\end{array}$} & \multicolumn{2}{|c|}{$\begin{array}{c}\text { Left Side-shift } \\
1 \mathrm{~cm} \text { right shoe lift }\end{array}$} & \multicolumn{2}{|c|}{$\begin{array}{c}\text { Left Side-shift } \\
3 \mathrm{~cm} \text { right shoe lift }\end{array}$} & \multicolumn{2}{|c|}{$\begin{array}{l}\text { Left Side-shift } \\
1 \mathrm{~cm} \text { left shoe lift }\end{array}$} & \multicolumn{2}{|c|}{$\begin{array}{l}\text { Left Side-shift } \\
3 \mathrm{~cm} \text { left shoe lift }\end{array}$} \\
\hline & Mean (SD) & $\mathrm{P}$-value & Mean (SD) & $\mathrm{P}$-value & Mean (SD) & $\mathrm{P}$-value & Mean (SD) & $\mathrm{P}$-value \\
\hline$\alpha 1 \mathrm{Min}$ & 0.51 (1.7) & 0.37 & $0.75(1.1)$ & 0.08 & $-0.3(0.4)$ & 0.16 & $-3.39(4.1)$ & $0.01^{*}$ \\
\hline$\alpha 1$ Max & 3.20 (8.6) & 0.08 & $1.34(1.1)$ & $0.002^{*}$ & $0.25(0.6)$ & 0.43 & $5.72(10.4)$ & 0.08 \\
\hline$\alpha 2$ Min & $0.78(2.8)$ & 0.56 & $0.50(0.9)$ & 0.23 & $-0.45(0.6)$ & 0.06 & $-0.55(5.2)$ & 0.43 \\
\hline$\alpha 2 \operatorname{Max}$ & 3.05 (9.7) & 0.49 & $0.46(1.2)$ & 0.28 & $0.22(0.8)$ & 0.56 & $7.15(10.4)$ & $0.03^{*}$ \\
\hline
\end{tabular}


Table 3 - Difference between means (maximum and minimum) of $\alpha 1, \alpha 2, \alpha 3$ and $\alpha 4$ in side-shift movements to the left with shoe lifts of $1 \mathrm{~cm}$ and $3 \mathrm{~cm}$ in relation to the static position and $p$ value

(Conclusion)

\begin{tabular}{|c|c|c|c|c|c|c|c|c|}
\hline \multirow{2}{*}{$\begin{array}{l}A \\
N \\
G \\
G \\
L \\
E \\
S\end{array}$} & \multicolumn{2}{|c|}{$\begin{array}{c}\text { Left Side-shift } \\
1 \mathrm{~cm} \text { right shoe lift }\end{array}$} & \multicolumn{2}{|c|}{$\begin{array}{c}\text { Left Side-shift } \\
3 \mathrm{~cm} \text { right shoe lift }\end{array}$} & \multicolumn{2}{|c|}{$\begin{array}{l}\text { Left Side-shift } \\
1 \mathrm{~cm} \text { left shoe lift }\end{array}$} & \multicolumn{2}{|c|}{$\begin{array}{l}\text { Left Side-shift } \\
3 \mathrm{~cm} \text { left shoe lift }\end{array}$} \\
\hline & Mean (SD) & $\mathrm{P}$-value & Mean (SD) & P-value & Mean (SD) & $\mathrm{P}$-value & Mean (SD) & $\mathrm{P}$-value \\
\hline$\alpha 3 \mathrm{Min}$ & $-2.86(5.5)$ & $0.01^{*}$ & $-2.54(1.1)$ & $0.002^{*}$ & $0.34(1)$ & 0.32 & $-1.46(4.9)$ & 0.77 \\
\hline$\alpha 3$ Max & $-1.92(5.0)$ & 0.19 & $-1.03(1.5)$ & 0.08 & $1.17(0.8)$ & $0.004^{*}$ & $0.2(5.0)$ & 0.43 \\
\hline$\alpha 4 \operatorname{Min}$ & $5.45(17.4)$ & 0.49 & $1.75(17.0)$ & 0.08 & 6.69 (18.2) & $0.03^{\star}$ & $7.74(18.9)$ & 0.06 \\
\hline$\alpha 4 \operatorname{Max}$ & $-1.16(3.7)$ & 0.37 & $-3.94(3.6)$ & $0.004^{*}$ & 0.61 (3.4) & 0.08 & $-0.04(7.8)$ & 0.56 \\
\hline
\end{tabular}

Note: ${ }^{*} p<0.05$

** marginal difference

Table 4 - Difference between means (maximum and minimum) of al, $\alpha 2, \alpha 3$ and $\alpha 4$ in the static position with shoe lifts of $1 \mathrm{~cm}$ and $3 \mathrm{~cm}$ in relation to the static position without shoe lift and $p$ value

\begin{tabular}{|c|c|c|c|c|c|c|c|c|}
\hline \multirow{2}{*}{$\begin{array}{l}A \\
N \\
G \\
L \\
E \\
S\end{array}$} & \multicolumn{2}{|c|}{$\begin{array}{l}\text { Static Position } \\
1 \mathrm{~cm} \text { right shoe lift }\end{array}$} & \multicolumn{2}{|c|}{$\begin{array}{c}\text { Static Position } \\
3 \mathrm{~cm} \text { right shoe lift }\end{array}$} & \multicolumn{2}{|c|}{$\begin{array}{l}\text { Static Position } \\
1 \mathrm{~cm} \text { left shoe lift }\end{array}$} & \multicolumn{2}{|c|}{$\begin{array}{c}\text { Static Position } \\
3 \mathrm{~cm} \text { left shoe lift }\end{array}$} \\
\hline & Mean (SD) & $\mathrm{P}$-value & Mean (SD) & $\mathrm{P}$-value & Mean (SD) & $\mathrm{P}$-value & $\begin{array}{l}\text { Mean } \\
\text { (SD.) }\end{array}$ & $\mathrm{P}$-value \\
\hline$\alpha 1 \mathrm{Min}$ & $0.97(3.0)$ & 0.38 & $1.9(2.2)$ & $0.04^{*}$ & $0.05(3.1)$ & 0.49 & $0.15(0.6)$ & 0.63 \\
\hline$\alpha 1$ Max & $-0.98(2.1)$ & 0.13 & $0.04(1.2)$ & 0.85 & $-0.65(0.9)$ & 0.06 & $-1.24(0.9)$ & $0.002^{*}$ \\
\hline$\alpha 2$ Min & $3.9(2.7)$ & $0.004^{*}$ & $4.5(2.6)$ & $0.002^{*}$ & $0.29(1.4)$ & 0.77 & $-0.31(1.9)$ & 0.63 \\
\hline a2 Max & $-0.03(1.1)$ & 1 & $0.18(0.8)$ & 0.49 & $-2.63(1.3)$ & $0.002^{*}$ & $-3.06(1.8)$ & $0.004^{*}$ \\
\hline$\alpha 3 \operatorname{Min}$ & $7.5(5.4)$ & $0.002^{*}$ & $4.68(1.9)$ & $0.002^{*}$ & $0.95(1.1)$ & $0.03^{*}$ & $2.29(2.0)$ & $0.02^{*}$ \\
\hline a3 Max & $1.31(4.2)$ & 0.63 & $-1.74(2.9)$ & 0.08 & $-5.64(3.6)$ & $0.002^{*}$ & $-3.69(4.2)$ & $0.037^{*}$ \\
\hline a4 Min & $2.82(4.9)$ & 0.06 & $1.42(3.5)$ & 0.19 & $6.49(19.1)$ & 0.06 & $9.9(17.9)$ & 0.06 \\
\hline$\alpha 4$ Max & $-3.09(4.2)$ & $0.03^{*}$ & $-3.64(1.7)$ & $0.004^{*}$ & $-5.94(5.0)$ & $0.004^{*}$ & $-3.97(4.9)$ & $0.014^{*}$ \\
\hline
\end{tabular}

Note: ${ }^{\star} p<0.05$

** marginal difference

The difference between means (maximum and minimum) of $\alpha 1, \alpha 2, \alpha 3$ and $\alpha 4$ of side-shift movements for both sides in isolation were also analyzed in relation to the static position. However, there was no significant difference in any analyzed data ( $p>0.3)$.

\section{Discussion}

The main goal of this study was to assess the influence of the side-shift movement associated or not with the use of a high or low shoe lift in subjects with idiopathic scoliosis. Some studies (4) have shown that the side-shift movement to the side of the highest curve convexity (thoracic) and the shoe lift on the same side as the lumbar curve convexity $(11,12,21)$ has the effect of improving alignment in the scoliosis. Besides the type of intervention, the best results for conservative treatment are obtained when they comprise an angulation deformity between $10^{\circ}$ to $25^{\circ}$ of the Cobb angle measurements (22).

It can be observed that the only angles that followed this tendency were those that resulted from side-shift movements to both sides, allied with left shoe lift (except in the situation with right side-shift movement with right shoe lift in the minimum $\alpha 2$ ), in which the sacral and thoracolumbar angles ( $\alpha 4$ and $\alpha 3$ respectively) were those that responded most 
to the intervention. As there were no studies in this area, until this moment, it can be observed that the movement allied with the use of a shoe lift obtained less significant results when compared to the effect of shoe lift use in the static position. Thus the movement, both to the convexity and to the opposite side, seems to diminish the shoe lift effect, both in the higher ( $\alpha 1$ and $\alpha 2)$ and lower ( $\alpha 3$ and $\alpha 4)$ postural angles.

In the present study, the side-shift movement to both sides in isolation, in comparison to the static position, did not present a significant difference or influence the postural angles in any way, showing that an acute intervention alone is not effective, although an intervention with a greater number of stimulations could present a different result (23). As shown in the study by Maruyama et al. (24), using side-shift exercises to the side of the scoliotic curve as a treatment proved to be a useful option for scoliosis after skeletal maturity. Stehbens and Cooper (9) also obtained the same satisfactory results with this kind of treatment.

Still related to the side-shift movement, as there was no control group for comparison it was not possible to find results related to the influence of the movement on the curve flexibility. The study of Ferreira and Barela (4) conducted with a control group and subjects with double curved scoliosis found no significant differences for alpha angles in either group, although the measurements of alpha posture angles, when not equal, were very close to those of the control group. Therefore, the mentioned study showed that when a subject with scoliosis executes a side-shift movement, the outcome is deformity correction. This also happened in the study of Ferreira et al. (25) that assessed the influence of side-shift movements. This being said, as the present study did not perform the same comparison, this corrective effect could not be observed; nevertheless, further studies are needed to verify the influence of the side-shift movement as an intervention for subjects with idiopathic scoliosis, taking into account the comparison with a control group.

Besides the dynamic situations, the use of the high and low shoe lifts in the static position were analyzed It was observed that all maximum angles, when using the left shoe lift, presented a significant difference, noting that the highest means of changes in relation to the static position occurred in the maximum angles of $\alpha 2, \alpha 3$, and $\alpha 4$, however there was a significant difference in all postural angles. Beyond this, it was also observed that in all situations with the left shoe lift the differences were more significant than with the right shoe lift. These findings are consistent with other studies $(12,21)$ that claim the occurrence of higher angles in the thoracolumbar region, a transition region and far from the apical vertebrae (more rigid), indicating greater flexibility in this region and larger shoe lift effects were expected in the lower curves (13) in the alpha angles 3 and 4. According to Hawes and O'Brien (3) the secondary or compensatory curves are more flexible and could present more alterations when subjected to shoe lift or movement interventions. However, Zabjek et al. (14) indicate that the use of insoles, regardless of the curve type and amplitude, significantly decrease the Cobb angle.

On the other hand, when the shoe lift was used on the right side, the greatest changes were obtained in the minimum angles $\alpha 2$ and $\alpha 3$ for both heights of shoe lift. Consequently, it can be stated that the shoe lift, besides influencing sacral and thoracolumbar angles, also influences high thoracic angles $(\alpha 2)$ both minimum, with right shoe lift, and maximum, left shoe lift. However, the greatest alterations were in the lower postural angles as in the previously mentioned studies $(4,21)$.

High and low shoe lifts produced different effects in static and dynamic situations. In the side-shift movements to both sides, allied to the use of the high shoe lift, greater effects were observed when compared to the use of the low shoe lift, wherein, except in the side-shift movement to the left using a left shoe lift, the postural angles were close in order to rectify the spine curvature when greater stimulation (high shoe lift) was chosen for the subjects in this intervention. In the static position, with a high or low shoe lift, the same results were not observed, especially regarding the thoracolumbar and lumbar postural angles that showed that the lower shoe lifts produced a greater effect when compared to the higher shoe lifts. This demonstrates that a static intervention with a shoe lift does not have a linear relationship with its height, as found by Zabjek et al. (14). However, in a dynamic situation the shoe lift height should be taken into account, as shown in these study results, since the side-shift movement, as stated above, acts by inhibiting the shoe lift effect, whereby greater stimulation needs to be given in order to achieve the effectiveness of a static intervention.

According to Bricot (26), scoliosis develops itself as a tonic postural system disease and not as a fatality, acting in it as a simple line of conduct, not knowing the postural system, can result in a disappointing 
effect. Postural control is extremely important in the ability to maintain balance in an upright position relying on the sensory system and musculoskeletal biomechanics (27). Thus, a precise assessment of the static position must be performed with minimum influence from postural balance and a good correlation with radiographic methods (28), aiming to help the therapist in the best choice for patient intervention.

Besides the shoe lift, proprioceptive insoles present some benefits such as deformity accommodation, giving support and stability through pressure relief at certain points of high compression. According to Mantovani et al. (29), insoles promote adequate postural realignment making the assessment of feet dysfunctions necessary to understand the postural influences. In this context, for individuals with idiopathic scoliosis, an efficient feet sensor assessment can help the therapist choose the most efficient intervention by using insoles or shoe lifts.

On the other hand, the asymmetrical functioning of the masticatory muscles can also present a compensatory role in postural balance $(30,31)$, in addition to clinical conditions such as temporomandibular dysfunctions which can result in jaw limitations, pain and functional incapability (32). A study by D'Avila et al. (33) reported that a unilateral posterior crossbite produces occipital axis deviation thus resulting in a unilateral pelvic anteriorization, pelvic inclination and a hint of gibbosity. Therefore, more studies are needed on the sensors, aiming to verify which factors can generate these compensations, which result in the pathology in question, in other words, scoliosis.

This study had two limitations that could have produce better and more consistent results: sample size and lack of control group. In this study, ten subjects with only one specific type of scoliosis were analyzed; however, due to this specificity it was difficult to find a larger number of subjects with this kind of curvature. Moreover, the lack of a control group limited the conclusive data, since there was no normality pattern with which to compare the results; it has been shown in the literature that in some situations, interventions closer to normality could be considered as effective ways to treat idiopathic scoliosis (25). Thus, in future studies in this field, the sample size and presence of a control group or comparisons with other types of intervention should be noted.

\section{Conclusion}

The influence of the side-shift movement allied to high or low shoe lifts on both sides was proven to be effective, although the shoe lift alone in the static position produced more significant changes and, thus, is considered a better type of intervention to avoid progression of double curve in subjects with idiopathic scoliosis. The immediate effect of this intervention (shoe lift allied to the side-shift movement) only in subjects with idiopathic scoliosis occurred in both high thoracic and lumbar region postural angles, producing greater changes in lower postural angles.

Therefore, the influence of the shoe lift in isolation or allied to the side-shift movement to both sides showed an immediate effect in order to rectify the spine of subjects with idiopathic scoliosis, with a more significant difference when using the shoe lift alone. Nevertheless, more studies are needed to verify whether this immediate effect remains in longterm interventions.

\section{References}

1. Nowotny J, Nowotny-Czupryna 0, Czupryna K. Various attitudes to the use of corrective exercises in conservative treatment of scoliosis [abstract]. Ortop Traumatol Rehabil. 2010;12(1):1-11.

2. Asher MA, Burton DC. Adolescent idiopathic scoliosis: natural history and long-term treatment effects [serial on the internet]. Scoliosis. 2006;1(2)[cited in dec. 18 2013].Available from: http://www.scoliosisjournal. com/content/1/1/2.

3. Hawes MC, O'Brien JP. The transformation of spinal curvature into spinal deformity pathological processes and implications for treatment. Scoliosis. 2006;1(3) [cited in dec. 18 2013]. Available from: http://www. scoliosisjournal.com/content/1/1/3.

4. Ferreira DMA, Barela JA. Análise da influência do calço e do movimento de inclinação lateral da coluna vertebral em indivíduos com escoliose idiopática [Thesis]. Rio Claro: Universidade Estadual Paulista, Departamento de Educação Física. 2009. 
5. Negrini S, Aulisa AG, Aulisa L, Circo AB, Mauroy JC, Durmala J, et al. 2011 SOSORT guidelines: Orthopaedic and Rehabilitation treatment of idiopathic scoliosis during growth [serial on the internet] Scoliosis. 2012;7(3) [cited in jul. dec 2012]. Available from: http://www.scoliosisjournal.com/content/7/1/3.

6. Hresko MT. Idiopathic Scoliosis in Adolescents. N Engl J Med. 2013;368(9):834-41.

7. Fusco C, Zaina F, Atanasio S, Romano M, Negrini A, Negrini S. Physical exercises in the treatment of adolescent idiopathic scoliosis: An updated systematic review. Physiother Theory Pract. 2011;27(1):80-114

8. Bridwell KH, Glassman S, Horton W, Shaffrey C, Schwab F, Zebala LP, et al. Does treatment (nonoperative and operative) improve the two-year quality of life in patients with adult symptomatic lumbar scoliosis: a prospective multicenter evidence-based medicine study. Spine. 2009;34(20):2171-8

9. Sthebens WE, Cooper RL. Regression of juvenile idiopathic scoliosis. ExpMolPathol. 2003. 74:326-35.

10. Moore KL, Dalley AF, Agur AMR. Anatomia Orientada para a Clinica. 6. ed. Rio de Janeiro: Guanabara Koogan; 2012.

11. Ferreira DMA, Barela AMF, Barela JA. Influência de calços na orientação postural de indivíduos com escoliose idiopática. FisioterMov. 2013;26:337-48.

12. Bruyneel AV, Chavet P, Bollini G, Allard P, Berton E, Mesure S. Lateral steps reveal adaptive biomechanical strategies in adolescent idiopathic scoliosis. Ann Med Phys (Lille). 2008;51(8):630-41.

13. Irvin RE. Reduction of lumbar scoliosis by use of a heel lift to level the sacral base. J Am Osteopath Assoc. 1991;91(1)34-44.

14. Zabjek KF, Leroux MA, Coillard C, Martinez X, Griffet J, et al. Acute postural adaptations induced by a shoe lift in idiopathic scoliosis patients. Eur Spine J 2001;10(2):107-13.

15. Weiss H-R. Intervention studies on scoliosis - Review of the reviews. Pol. Ann. Med. 2012; 19(1):72-83.

16. Huang S-C. Cutt-off point of the scoliometer in school scoliosis screening. Spine. 1997;22(17):1985-9.

17. Korovessi PG, Tamatakis MV. Prediction of scoliotic Cobb angle with the use of the scoliometer. Spine. 1996;21(14):1661-6.
18. Engsberg JR, Bridwell KH, Wagner JM, Uhrich ML, Blanke K, Lenke LG. Gait changes as the result of deformity reconstruction surgery in a group of adults with lumbar scoliotics. Spine. 2003;28(16):1836-43.

19. Feipel V, Aubin CE, Ciolofan OC, Beauséjour M, Labelle H, Mathieu PA. Electromyogram and kinematic analysis of lateral bending in idiopathic scoliosis patients. Med Biol Eng Comput. 2002;40:497-505.

20. Leroux MA, Zabjek K, Simard G, Badeux J, Coillard C, Rivard C. A noninvasive anthropometric technique for measuring kyphosis and lordosis - an application for idiopathic scoliosis. Spine. 2000;25(13):1689-94.

21. Modi HN, Suh SW, Song HR, Yang JH, Kim HJ, Modi CH. Differential wedging of vertebral body and intervertebral disc in thoracic and lumbar spine in adolescent idiopathic scoliosis - a cross sectional study in 150 patients [serial on the internet]. Scoliosis. 2008;3(11) [cited in Dec. 15 2013]. Available from: http://www. scoliosisjournal.com/content/3/1/11.

22. Bialek M. Conservative treatment of idiopathic scoliosis according to FITS concept: presentation of the method and preliminary, short term radiological and clinical results based on SOSORT and SRS criteria [serial on the internet]. Scoliosis. 2011;6(25) [cited in Dec. 13 2013]. Available from: http://www.scoliosisjournal.com/content/6/1/25.

23. Borysov M, Borysov A. Scoliosis short-term rehabilitation (SSTR) according to 'Best Practice' standards - are the results repeatable? [serial on the internet]. Scoliosis. 2012;7(1) [cited in Dec. 15 2013]. Available from: http://www.scoliosisjournal.com/content/7/1/1.

24. Maruyama T, Kitagawa T, Takeshita K, Mochizuki K, Nakamura K. Conservative treatment for adolescent idiopathic scoliosis: can it reduce the incidence of surgical treatment. Ped Rehab. 2003;6(3-4):215-19

25. Ferreira DMA, Carnielli AL, Ninello DA, Pachioni CAS, Fregonesi CEPT, Camargo MR. A influência do movimento de inclinação lateral na cifose torácica e na lordose lombar de indivíduos com escoliose idiopática. Ter Man. 2010;8(38):325-31.

26. Bricot, B. Posturologia. 2. ed. São Paulo: Ícone; 2004.

27. Mann RA, Hagy JL. The function of the toes in walking, jogging and running. ClinOrthop. 2004;142:24-9. 
28. Krejci J, Gallo J, Stepanik P, Salinger J. Optimization of the examination posture in spinal curvature assessment [serial on the internet]. Scoliosis. 2012;7(10) [cited in Dec. 20 2013]. Available from: http://www. scoliosisjournal.com/content/7/1/10.

29. Mantovani AM, Martinelli AR, Savian NU, Fregonesi CEPT, Lança AC. Palmilhas proprioceptivas para o controle postural. Colloquium Vitae. jul/dec. 2010;2(2):34-8.

30. Shimazaki T, Motoyoshi M, Hosoi K, Namura S. The effect of occlusal alteration and masticatory imbalance on the cervical spine. Eur J Orthod. 2003;25(5):457-63.

31. Zhou S, Yan J, Da H, Yang Y, Wang N, Wang W, et. al. Scoliosis short-term rehabilitation (SSTR) according to 'Best Practice' standards - are the results repeatable? PloS ONE. 2013;8(3).
32. Geres GS, Pachioni CAS, Masselli MR, Ferreira DMA, Gomes DCA, Pachioni FSM et. al. Análise de condições clínicas em estudantes com disfunção temporomandibular. Ter Man. 2013;11(53):361-6.

33. D’Avila NBR, Novo NF, Juliano Y, Martinez JA, Júnior VC. Estudo dos sinais de escoliose em crianças com ou sem mordida cruzada posterior unilateral. Rev. bras. ciênc. Saúde. 2010;8(24):27-34.

Recebido: 20/12/2013

Received: $12 / 20 / 2013$

Aprovado: $14 / 07 / 2015$

Approved: 07/14/2015 